International Journal of Current Advanced Research

ISSN: O: 2319-6475, ISSN: P: 2319 - 6505, Impact Factor: SJIF: 5.995

Available Online at www.journalijcar.org

Volume 6; Issue 5; May 2017; Page No. 3998-3999

DOI: http://dx.doi.org/10.24327/ijcar.2017.3999.0416

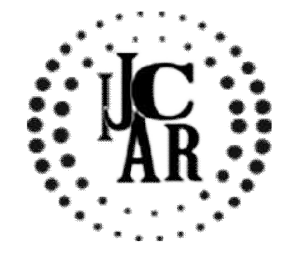

Research Article

\title{
CERTAIN SURFACE PROPERTIES OF BENTONITE AND SILICA AQUEOUS COLLOIDS
}

\author{
Patel H. A
}

Sir P. T. Science College, Modasa, Sabarakatha, Gujarat, India

\begin{tabular}{|c|c|}
\hline 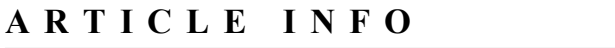 & A B S T R A C T \\
\hline Article History: & \multirow{4}{*}{$\begin{array}{l}\text { In the development of Nanoscience and Nanotechnology, surface properties of the material } \\
\text { plays important role. Recent advances in nanomaterials science have made increasingly } \\
\text { possible the design of surfaces with specific and tunable properties. Such surfaces have a } \\
\text { broad range of applications from microfluidics to biosensors and biomimetics. One of the } \\
\text { best example of superhydrophobic surface is "lotus leaf". Nanofluid is a fluid containing } \\
\text { nanometer-sized particles, called nanoparticles. Nanofluids have novel properties that make } \\
\text { them potentially useful in many applications in heat transfer, including microelectronics, } \\
\text { fuel cells, pharmaceutical processes, and hybrid-powered engines, Engine cooling/vehicle } \\
\text { thermal management,domestic refrigerator, chiller, heat exchanger, and nuclear reactor,in } \\
\text { grinding, in machining, in Space, defense and ships,. They exhibit enhanced thermal } \\
\text { conductivity and the convective heat transfer coefficient compared to the base fluid. }\end{array}$} \\
\hline $\begin{array}{l}\text { Received } 8^{\text {th }} \text { February, } 2017 \\
\text { Received in revised form } 15^{\text {th }} \text { March, } 2017 \\
\text { Accepted } 14^{\text {th }} \text { April, } 2017 \\
\text { Published online } 28^{\text {th }} \text { May, } 2017\end{array}$ & \\
\hline Key words: & \\
\hline $\begin{array}{l}\text { Nanoparticles, Superhygroscopic, tunable, } \\
\text { Bentonite Suspension, heat transfer, hydrofobic }\end{array}$ & \\
\hline
\end{tabular}

Copyright $₫ 2017$ Patel H. A. This is an open access article distributed under the Creative Commons Attribution License, which permits unrestricted use, distribution, and reproduction in any medium, provided the original work is properly cited.

\section{INTRODUCTION}

Silica is found in many parts of human body. It is required for tissue and plant growth. Silica is a common additive in the production of foods, where it is used primarily as a flow agent in powdered foods, or to absorb water in hygroscopic applications. Bentonite is water adsorbent and has excellent colloidal properties; it is often used in drilling mud for oil and gas wells and for geotechnical and environmental investigations. The swelling also makes sodium bentoniteuseful as a sealent in making slurry walls, waterproffing of below-grade walls and forming other impermeable barriers, e.g. to seal off the annulus of a water well, to plug old wells. Relatively small quantity of bentonite suspended in water form a viscous, shear thinning material. At high enough concentration (60 grams of bentonite per litre of suspension) bentonite suspension begins to take on the characteristics of a gel. Bentonite is a high performance desiccant used to protect a variety of products from moisture degradation, maintaining product quality and shelf life and widely used in pharmaceutical, nutraceutical and diagnostic packing applications. Because of its adsorptive properties, environmental benefits and cost effectiveness, bentonite is an ideal desiccant and viable alternative to traditional desiccants such as silica gel for healthcare packing applications.

Because of all these reasons, in this paper we present a comparative investigation of silica and bentonite aqueous suspension for their concentration dependent surface properties.

*Corresponding author: Patel H. A

Sir P. T. Science College, Modasa, Sabarakatha, Gujarat, India

\section{MATERIAL AND METHODS}

In this work we have prepared stable aqueous colloidal suspension using a bentonite particles (plate shaped particles with width $\sim 600 \mathrm{~nm}$ and thickness $\sim 1 \mathrm{~nm}$ ), and $\sim 500 \mathrm{~nm}$ size silica spheres. We have used suitable surfactants for both the particulate systems an used Jurin's Law for the comparative surface properties of silica and bentonite aqueous colloids.

\section{RESULTS AND DISCUSSION}

Both the particles are hygroscopic. However, their surface properties are quite different. It is observed that the surface tension as a function of their concentration decreases. In case of bentonite the decrement in surface tension is nonexponential where as for silica spheres the decrement is exponential. This may be due to its different behaviour in presence of water. We have also determined angle of contact for the same. This different hygroscopic behaviour can lead to novel applications in cosmetic industries as well.

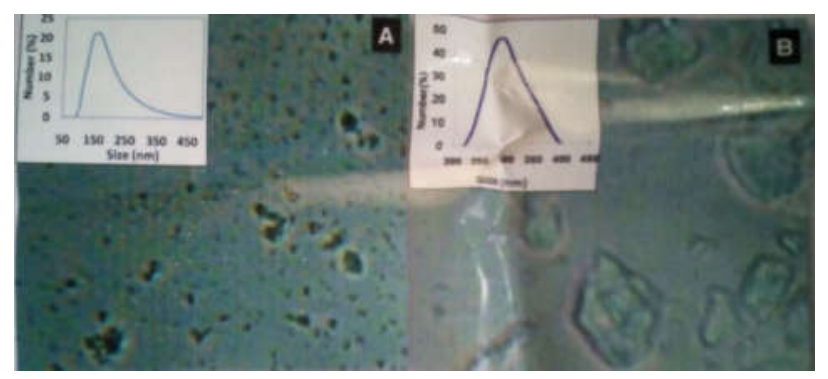

It is observed that as the concentration increases the surface tension in both the case decreases. But in the case of silica the decrease in surface tension is exponential whereas in the case 
of bentonite it is non-exponential. It is also observed that the drop of silica suspension has a spherical surface due to constant liquid pressure, whereas the drop of bentonite suspension has a pancake-shape, flattered by gravity and plate shape of particles.

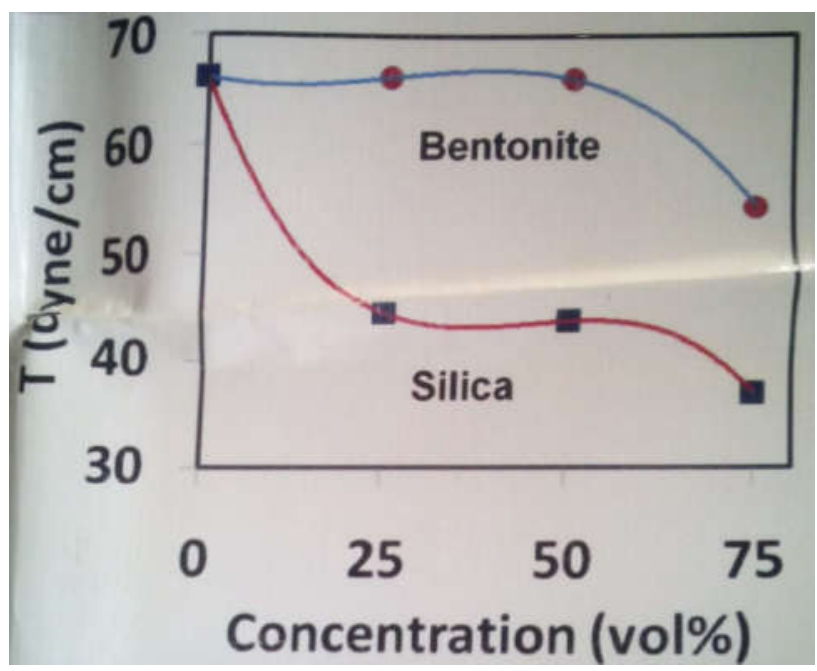

\section{CONCLUSION}

A stable aqueous suspension colloidal suspension is prepared by dispersing spherical silica particles and plate shaped bentonite particles. We have studied and compared their surface properties as both of them are good hygroscopic material. The contact angle of bentonite for their $75 \%$ volume concentration is 64 and that of silica suspension is $61 \%$. It is also observed that the silica suspension has spherical drop shape surface, where bentonite has pancake drop surface due to their shape of the particles. In bentonite suspension for the change in density of $10 \%$, the change in its surface tension is $18 \%$, whereas even for $5 \%$ change in density of silica suspension, its surface tension shows change of $44.5 \%$.
This suggests that the surface tension of silica suspension in this concentration range is more sensitive to its volume concentration than the bentonite suspension. The decrement of surface tension of both the suspension is quite different, for bentonite suspension the decrement of surface tension as a function of concentration is non-exponential. But for silica suspension the decrement is exponential. This different surface behaviour of hygroscopic material can be useful to develop tunable surfaces for nanofluidics and hydrophobic surfaces.

\section{References}

1. A.L. Yarin, volume 38 (2006) Drop Impact Dynamics: Splashind and spreading

2. Z. Wang, C. Lopez, A. Hirsa and N. Koratkar Splashing of high speed droplet, Appl. Phys.Lett.91, 023105(2007).

3. Y. C. Jung and B. Bhushan, Dynamic effects of bouncing water droples on Superhydrofobic surface, Langmuir 24,6262(2008)

4. Zorba, E. Stratakis, M. Barberoglou, E. Spanakis, P. Tzanetakis, S. H. Anastasiadis and C. Fotakis, Adv. Mater Biomimetic micro/nanostructured functional surfaces for microfluidic and tissue engineering applications, Weinheim, Ger.20,4049(2008).

5. P. C. Tsai, S. Pancheco, C. Pirat, L. Lefferts and D. Lohse, Droplelet move following wettability gradient, Langmuir 25,12293(2009).

6. T. Deng, K.K. Varanasi, M. Hsu, N. Bhate, C. Keimel, J. Stein and M. Blohm, Impact and wetting behaviours of impinging microdroplets, Appl. Phys.Lett. 94, 133109(2009).

7. M. Nosonovsky and B. Bhushan, J.Biomimatics: Structured surfaces, Phys. Condens. Matter 20, 395005(2008)

8. F. Brochard-Wyart, in: Capillarity and Wetting, Soft Matter Physics, (Ed.) M. Daoud, Springer, Heidelberg, 1999.

\footnotetext{
How to cite this article:

Patel H. A (2017) 'Certain Surface Properties Of Bentonite And Silica Aqueous Colloids ', International Journal of Current Advanced Research, 06(05), pp. 3998-3999.

DOI: http://dx.doi.org/10.24327/ijcar.2017.3999.0416
} 